DOI: $10.14746 / \mathrm{amp} .2016 .21 .4$

JAMES H. KROEGER

Loyola School of Theology - Manila

\title{
Pope Francis, Priesthood And Mission. Ten Inspirational Insights
}

Pope Francis, revered as a "people's pope," connects and interacts well with people across a wide spectrum of ages, backgrounds, social strata and walks of life. He is noted for a large number of "firsts:" the first Jesuit pope, the first to take the name Francis, the first non-European pope in more than 1,000 years, and the first pope to be honored in 2013 by Time as the "Person of the Year" and awarded the prestigious title given to the one who "has done the most to influence the events of the year."

Pope Francis, who has over ten million followers on Twitter, is often remembered for his sense of humor and memorable quotes. When he was elected pope in 2013, he told the other cardinals: "May God forgive you for what you have done." A child once asked him if he wanted to be pope and this was his response: "You have to be totally crazy to want to be pope." His quotes contain much profound wisdom, expressed succinctly and in a memorable manner. "A little bit of mercy makes the world less cold and more just." "To be wise, use three languages: think well, feel well, and do well. And to be wise, allow yourselves to be surprised by the love of God!"

In addition to insights on a broad range of current topics, Pope Francis has spoken profoundly and insightfully on priests and the priesthood on a variety of occasions (e.g. Chrism Masses, Ordination Masses, Jubilee for Priests, etc.). This modest presentation attempts to mine the rich treasures of Francis' insights on priesthood, quoting extensively the very words spoken by the pope, which revolve about ten pivotal themes. Admittedly, this is only one author's attempt to "thematize" the thoughts of Pope Franciscus on the priesthood. Twenty-four of the most relevant documents that contain "priesthood material" are cited (see the final page for bibliographic sources and the method of citation). One now turns directly to elucidating the "priestly thoughts" of Pope Francis. 


\section{Anchor Your Priesthood in Your Relationship with Christ}

In his first apostolic exhortation, Evangelii Gaudium (3), Francis directly invited everyone (priests in particular) to daily meetings with Jesus. "I invite all Christians, everywhere, at this very moment, to a renewed personal encounter with Jesus Christ [...]. I ask all of you to do this unfailingly each day. No one should think that this invitation is not meant for him or her [...]. The Lord does not disappoint those who undertake this risk; whenever we take a step towards Jesus, we come to realize that he is already there, waiting for us with open arms" (CC). "Each of us is very dear to God, who loves us, chooses us and calls us to serve [...]. We would do well each day to pray trustingly for this, asking to be healed by Jesus, to grow more like him who "no longer calls us servants but friends' (Jn 15:15)" (SS). This is a clear challenge for priests: to live in conformity to Christ in the midst of the world of today. Expressed simply, all is anchored in one's friendship with Jesus.

Pope Francis spoke about the priest's "tiredness" in his 2015 Chrism Mass homily, noting how it can bring us closer to Christ. "The tiredness of priests! Do you know how often I think about this weariness which all of you experience? I think about it and I pray about it, often, especially when I am tired myself [...]. Whenever we feel weighed down by pastoral work, we can be tempted to rest however we please, as if rest were not itself a gift of God [...]. Our weariness is precious in the eyes of Jesus who embraces us and lifts us up [...]. Let us never forget that a key to fruitful priestly ministry lies in how we rest and in how we look at the way the Lord deals with our weariness. How difficult it is to learn how to rest! This says much about our trust and our ability to realize that we too are sheep; we need the help of the Shepherd" (KK). We need to learn to rest in the arms of the Good Shepherd.

During the 2016 Jubilee for Priests, Pope Francis, celebrating the Eucharist on the Feast of the Sacred Heart, noted that we must always "contemplate two hearts: the Heart of the Good Shepherd and our own heart as priests. The Heart of the Good Shepherd is not only the Heart that shows us mercy, but is itself mercy [...]. There I know I am welcomed and understood as I am; there, with all my sins and limitations, I know with certainty that I am chosen and loved. Contemplating his heart, I renew my first love; the memory of that time when the Lord touched my soul and called me to follow him, the memory of the joy of having cast the nets of our life upon the sea of his Word" (WW). "Never forget your first love. Never!" (GG)

Certainly, for priests, our relationship with Christ is intimately linked into the Eucharist. "Through your ministry, the spiritual sacrifice of the faithful is made perfect, for it is united to the sacrifice of Christ, which through your hands in the name of the whole of the Church is offered up in a bloodless way 
on the altar in the celebration of the holy mysteries. When you celebrate the Mass, understand, therefore, what you are doing. Do not do it in haste! Imitate what you celebrate - it is not an artificial rite, an artificial ritual - so that participating in the mystery of the Lord's death and resurrection, you may bear the death of Christ in your members and walk with him in the newness of life" (LL).

As priests, we "cannot live without a vital, personal, authentic and solid relationship with Christ [...]. [One] who is not daily nourished by the Food will become a bureaucrat [...]. Daily prayer, assiduous reception of the sacraments, particularly the Eucharist and Reconciliation, daily contact with the Word of God and a spirituality which translates into lived charity - these are vital nourishment for each of us. Let it be clear to all of us that apart from Him we can do nothing (cf. Jn 15:8)" (HH).

\section{As a Merciful Shepherd, Be Close to Your People}

Pope Francis boldly stated: "People love their priests; they want and need their shepherds! The faithful never leave us without something to do, unless we hide in our offices or go out in our cars wearing sun glasses. There is a good and healthy tiredness. It is the exhaustion of the priest who wears the smell of the sheep, but also smiles the smile of a father rejoicing in his children or grandchildren [...]. If Jesus is shepherding the flock in our midst, we cannot be shepherds who are glum, plaintive or, even worse, bored. The smell of the sheep and the smile of a father" (KK).

"The joy of Jesus the Good Shepherd is not a joy for himself alone, but a joy for others and with others, the true joy of love. This is also the joy of the priest. He is changed by the mercy that he freely gives [...]. Dear priests, in the Eucharistic celebration we rediscover each day our identity as shepherds. In every Mass, may we truly make our own the words of Christ: 'This is my body, which is given up for you.' This is the meaning of our life; with these words, in a real way we can daily renew the promises we made at our priestly ordination. I thank all of you for saying 'yes'!" (WW).

Speaking of the "priest-shepherd in his parish or in the mission entrusted to him," Francis noted that this mission "brings him joy whenever he is faithful to it, whenever he does all that he has to do and lets go of everything that he has to let go of, as long as he stands firm amid the flock which the Lord has entrusted to him: 'Feed my sheep' (cf. Jn 21:16-17) [...] All who are called should know that genuine and complete joy does exist in this world: it is the joy of being taken from the people we love and then being sent back to them as dispensers of the gifts and counsels of Jesus, the one Good Shepherd who, 
with deep compassion for all the little ones and the outcasts of this earth, wearied and oppressed like sheep without a shepherd, wants to associate many others to his ministry, and just like Him, to remain with us and to work, in the person of his priests, for the good of his people" (EE). "Have always in mind the example of the Good Shepherd, who came not to be served but to serve; to seek and save that which was lost" (RR).

Priests will share in the sufferings of their people. "In our prayer we ask for the grace to 'feel and savor' the Gospel that it can make us more 'sensitive' in our lives [...]. We can ask for the grace to taste with the crucified Jesus the bitter gall of all those who share in his cross, and smell the stench of misery - in field hospitals [a favorite expression of Pope Francis], in trains and in boats crammed with people. The balm of mercy does not disguise this stench. Rather, by anointing it, it awakens new hope" (VV).

For Pope Francis, the work of priests does not consist of "purely mechanical jobs, like running an office, building a parish hall, or laying out a soccer field for the young of the parish [...]. The tasks of which Jesus speaks call for the ability to show compassion; our hearts are to be 'moved' and fully engaged in carrying out works of mercy. We are to rejoice with couples who marry; we are to laugh with the children brought to the baptismal fount; we are to accompany young fiancés and families; we are to suffer with those who receive the anointing of the sick in their hospital beds; we are to mourn with those burying a loved one [...]. For us priests, what happens in the lives of our people is not like a news bulletin: we know our people, we sense what is going on in their hearts. Our own heart, sharing in their suffering, feels 'com-passion,' is exhausted, broken into a thousand pieces, moved and even 'consumed' by the people" (KK).

The message for priests that Pope Francis frequently reiterates is expressed in his words spoken at the ordination of ten priests on Good Shepherd Sunday in 2013: "Today I ask you in the name of Christ and the Church: never tire of being merciful" (BB). When he ordained thirteen priests on May 11, 2014, Francis said: "And here I want to pause to ask you: for the love of Jesus Christ, never tire of being merciful! Please!" (FF). At the 2016 Chrism Mass, Francis noted: "As priests, we are witnesses to and ministers of the ever-increasing abundance of the Father's mercy; we have the rewarding and consoling task of incarnating mercy, as Jesus did" (QQ). Misericordiae Vultus, Francis' 2015 Bull of Indiction for the Extraordinary Jubilee of Mercy, overflows with copious insights on the mercy of God. In Evangelii Gaudium, Francis quotes Thomas Aquinas, asserting that "mercy is the greatest of all virtues" and "it is proper to God to have mercy" (EG 37). 


\section{Seek to Live a Modest Lifestyle; Be Available}

Although diocesan priests do not take the vow of poverty like religious priests, all priests commit themselves to living and practicing a simple style of life. It is well known that during his years in Buenos Aires, Cardinal Bergoglio lived in a small apartment rather than in an episcopal residence; he used public transportation rather than having a car with a driver; he cooked for himself. As the newly elected Pope, he rode with the other cardinals on the bus, paid his own hotel bill, and now he maintains a very modest car and lives in the Casa Santa Marta. Pope Francis knows the material needs necessary for the apostolate; however, he also challenges his fellow priests to examine their sincerity and authenticity in living their own spiritual poverty.

Francis admits: "In the Church we have, and have always had, our sins and failings [...]. Our people forgive us priests for our many failings, except for that of attachment to money. This does not have so much to do with money itself, but the fact that money makes us lose the treasure of mercy. Our people can sniff out which sins are truly grave for the priest, the sins that kill his ministry [...]. Being merciful is not only 'a way of life,' but 'the way of life.' There is no other way of being a priest" (VV).

How do priests become "good and faithful servants" (cf. Mt 25:21)? For Francis, "we are asked to be available [...]. Each morning he trains himself to be generous with his life and to realize that the rest of the day will not be his own, but given over to others [...]. One who serves is open to surprises, to God's constant surprises [...]. One who serves is not worried about the timetable. It deeply troubles me when I see a timetable in a parish: 'From such a time to such a time.' And then? There is no open door, no priest, no deacon, no layperson to receive people. This is not good [...]. If you show that you are available to others, your ministry will not be self-serving, but evangelically fruitful" (SS).

Francis has spoken frequently on the virtue of availability in priests. In his 2014 Chrism Mass, he noted: "The availability of her priests makes the Church a house with open doors, a refuge for sinners, a home for people living on the streets, a place of loving care for the sick, a camp for the young, a classroom for catechizing children about to make their First Communion [...]. Wherever God's people have desires or needs, there is the priest, who knows how to listen (ob-audire) and feels a loving mandate from Christ who sends him to relieve that need with mercy or to encourage those good desires with resourceful charity" (EE).

Pope Francis' commitment to simple living is concretely reflected in his choice of his Papal name: Francis. Many of the details of his "name-choice" are commonly known, since Francis himself narrated them. When it became 
clear that he was chosen, his friend, Cardinal Claudio Hummes who was seated next to him, hugged him, gave him a kiss, and said: "Don't forget the poor!" Francis said: "Those words came to me: the poor, the poor. Then, right away, thinking of the poor, I thought of Francis of Assisi. For me, he is the man of poverty." Francis added: "How I would like a Church which is poor and for the poor." In his Evangelii Gaudium, Francis has a major section on the inclusion of the poor in the Church and society (EG 186-216); he strongly reiterates his desire: "I want a Church which is poor and for the poor" (EG 198).

\section{Admit One's Limitations; Become a Model of Integrity}

The Letter to the Hebrews (5:1) states that "every high priest has been taken from among men and made their representative before God." Presbyterorum Ordinis, the Vatican II document on the Ministry and Life of Priests, asserts: "Priests, who are taken from among men and ordained for men in the things that belong to God in order to offer gifts and sacrifices for sins, nevertheless live on earth with other men as brothers" (PO 3). Priests are truly to be "in this world, but not of this world;" they need to be deeply aware of both their "nothingness"/ "humanness" as well as their "greatness"//dignity." Even in their weaknesses they are to manifest the overwhelming power and presence of the divine. The manifold workings of God's grace within our human limitations is indeed a profound mystery; we priests should allow ourselves to be overwhelmed by God's loving mercy - and shed tears of joyful gratitude!

Francis says: "That is how we [priests] have to see ourselves: poised between our utter shame and our sublime dignity. Dirty, impure, mean and selfish, yet at the same time, with feet washed, called and chosen to distribute the Lord's multiplied loaves, blessed by our people, loved and cared for. Only mercy makes this situation bearable. Without it, either we believe in our own righteousness like the Pharisees, or we shrink back like those who feel unworthy $[\ldots]$. The important thing is that each of us feel that fruitful tension born of the Lord's mercy: we are at one and the same time sinners pardoned and sinners restored to dignity" (TT). "The mercy of God [...] is always 'greater' than our consciousness of our sinfulness" (UU).

Pope Francis asserts that "A good priest, therefore, is first of all a man with his own humanity, who knows his own history, with its riches and its wounds, who has learned to make peace with this, achieving the fundamental serenity proper to one of the Lord's disciples [...]. Our humanity is the 'earthen vessel' in which we conserve God's treasure, a vessel we must take care of, so as to transmit well its precious contents [...]. He is the 'high priest,' at the same time close to God and close to man; he is the 'servant,' who washes the feet 
and makes himself close to the weakest; he is the 'good shepherd,' who always cares for his flock" (OO).

One can identify various faults and failures in priests, who receive harsh words from Pope Francis: the sins of careerism / authoritarianism / [and] "clericalism, which is a distortion of religion" (DD). There is the sin of "existential schizophrenia $[\ldots]$ the disease of those who live a double life, the fruit of that hypocrisy typical of the mediocre" (HH). On several occasions, Pope Francis told priests to be much more merciful to divorced Catholics and to welcome

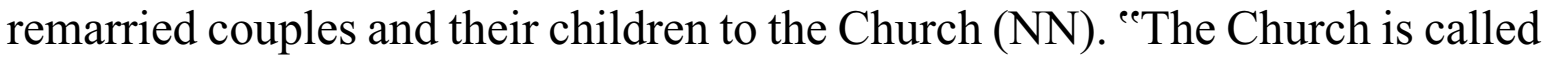
to be the house of the Father, with doors always wide open [...]. Everyone can share in some way in the life of the Church; everyone can be part of the community; nor should the doors of the sacraments [e.g. Baptism, Eucharist] be closed for simply any reason" (EG 47).

Therefore, priests need to constantly examine their conscience and style of life. Pope Francis offers a very brief examination of conscience for priests: "Where is my heart? Among the people, praying with and for the people, involved in their joys and sufferings, or rather among the things of the world, worldly affairs, my private space?" (OO). Another approach that Francis suggests is the "hymn to charity" in Saint Paul's first letter to the Corinthians as a guide and an examination of conscience (JJ). In addition, do we priests realize that we are "useless servants" (Lk 17:10), "whom the Lord blesses with the fruitfulness of his grace, seats us at his table, and serves us the Eucharist"? (VV). Priests - the entire Church - must never become "self-referential!" (VV).

\section{Exude Joy in Ministry; Receive and Give Affection}

The dominant theme for Pope Francis' second Chrism Mass reflection (2014) was "priestly joy." "We recall the happy day of the institution of the priesthood, as well as the day of our own priestly ordination. The Lord anointed us in Christ with the oil of gladness, and this anointing invites us to accept and appreciate this great gift: the gladness, the joy of being a priest. Priestly joy is a priceless treasure, not only for the priest himself, but for the entire faithful people of God: that faithful people from which he is called to be anointed and which he, in turn, is sent to anoint" (EE).

"Priestly joy has its source in the Father's love, and the Lord wishes the joy of this love to be 'ours' and to be 'complete' (Jn 15:11) [...]. There are three significant features of our priestly joy. It is a joy which anoints us [...], it is a joy which is imperishable, and it is a missionary joy which spreads and attracts [...]. A joy which anoints us. In a word, it has penetrated deep within our 
hearts; it has shaped them and strengthened them sacramentally [...]. We are anointed down to our very bones, and our joy, which wells up from deep within, is the echo of this anointing. An imperishable joy [...] which the Lord has promised no one can take from us (Jn 16:22) [...]. A missionary joy: priestly joy is deeply bound up with God's holy and faithful people [...] for baptizing and confirming them, healing and sanctifying them, blessing, comforting and evangelizing them" (EE).

Recall that the first major document issued by Pope Francis was Evangelii Gaudium (The Joy of the Gospel). For Francis, "The joy of the Gospel fills the hearts and lives of all who encounter Jesus [...]. With Christ joy is constantly born anew [...]. I wish to encourage the Christian faithful to embark upon a new chapter of evangelization marked by this joy" (EG 1).

Hidden in this first apostolic exhortation by Francis are several creative expressions to remind us of the centrality of joy in our apostolate. "There are Christians whose lives seem like Lent without Easter" (EG 6). "An evangelizer must never look like someone who has just come back from a funeral" (EG 10). We must be wary of a "tomb psychology" that "transforms Christians into mummies in a museum" (EG 83). Francis quoted Saint John XXIII, asserting that "We feel we must disagree with those prophets of doom who are always forecasting disaster, as though the end of the world were at hand" (EG 84). Christians must avoid anything that "turns us into querulous and disillusioned pessimists, "sourpusses"” (EG 85). "Let us not allow ourselves to be robbed of the joy of evangelization!" (EG 83).

For Francis, a priest should be a true apostle, "a person who transmits joy everywhere he goes. A heart filled with God is a happy heart that radiates an infectious joy; it is immediately evident! So let us not lose that joyful, humorous and even self-deprecating spirit which makes people amiable even in difficult situations. How beneficial is a good dose of humor! We would do well to recite often the prayer of Saint Thomas More. I say it every day" (HH). The final line of More's prayer is: "Grant me, O Lord, a sense of good humor. Allow me the grace to be able to take a joke and to discover a bit of joy in life and to be able to share it with others" (HH).

Pope Francis has fervently implored the Lord for the gift of joy for priests. "On this priestly Thursday, I ask the Lord Jesus to preserve the joy sparkling in the eyes of the recently ordained [...]. Preserve, Lord, in your young priests the joy of going forth, of doing everything as if for the first time, the joy of spending their lives fully for you [...]. I ask the Lord to confirm the priestly joy of those who have already ministered for some years [...], those who bear the burden of the ministry [...]. I ask the Lord Jesus to make better known the joy of elderly priests, whether healthy or infirm. It is the joy of the Cross [...]. May they know the joy of handing on the torch, the joy of seeing new genera- 
tions of their spiritual children, and of hailing the promises from afar, smiling and at peace, in that hope which does not disappoint" (EE).

\section{Be Committed to Quality Preaching}

Many Catholics were surprised when Pope Francis in Evangelii Gaudium devoted twenty-five sections to the homily and preaching (EG 135-159). Francis made several straightforward - even blunt - statements about priests and preaching. "The homily is the touchstone for judging a pastor's closeness and ability to communicate to his people" (135). "The homily cannot be a form of entertainment [...]. It should be brief and avoid taking on the semblance of a speech or a lecture [...]. If the homily goes on too long, it will affect two characteristic elements of the liturgical celebration: its balance and its rhythm"(138). "Preparation for preaching is such an important task that a prolonged time of study, prayer, reflection and pastoral creativity should be devoted to it [...]. A preacher who does not prepare is not 'spiritual'; he is dishonest and irresponsible with the gifts he has received" (145).

The homily "should not be used to correct errors [...], it should not be employed to teach doctrine [...], it should not be used to expound various theological opinions [...], let us not use it to talk about the latest news" (147). "What is essential is that the preacher be certain that God loves him, that Jesus Christ has saved him and that his love always has the last word" (151). "Preparation for preaching thus becomes an exercise in evangelical discernment" [linking profound faith to contemporary life] (154). "Another feature of a good homily is that it is positive [...]. Positive preaching always offers hope, points to the future, does not leave us trapped in negativity" (159).

Speaking to newly ordained priests, Francis said: "May your homilies not be boring; may your homilies touch the heart of the people because they come from your heart, because what you are telling them is what you carry in your heart. It is in this way that the Word of God is passed on, and thus your teaching will be a joy and support to Christ's faithful; the fragrance of your lives will be your testimony" (LL). One readily recalls here the episcopal motto of John Henry Cardinal Newman: Cor ad cor loquitur [Heart speaks to heart].

"A good priest can be recognized by the way his people are anointed; this is clear proof. When our people are anointed with the oil of gladness, it is obvious: for example, when they leave Mass looking as if they have heard good news. Our people like to hear the Gospel preached with 'unction,' they like it when the Gospel we preach touches their daily lives [...], when it brings light to moments of extreme darkness [...]. People thank us because they feel we 
have prayed over the realities of their everyday lives, their troubles, their joys, their burdens, and their hopes" (AA).

\section{Carefully Monitor any "Clerical Position or Power" You Possess}

Perhaps the most pointed address of Pope Francis to alert priests and bishops to some possible pitfalls in their ministry and life is found in his 2014 Christmas message to the Roman Curia ( $\mathrm{HH})$. The message was crafted as a kind of "examination of conscience," following the practice of the Desert Fathers, who wrote "lists" as a preparation for the Sacrament of Reconciliation. Francis noted that healing comes about through an awareness of one's sickness and the personal and communal decision to patiently and perseveringly apply the appropriate remedies.

Francis mentioned some of the probable "diseases and temptations which weaken our service to the Lord," which can weaken our "vital, personal, authentic and solid relationship with Christ." Mentioning several specific items provides clarity and can foster "a living relationship with God that nourishes and strengthens our communion with others." The "disease list" of Pope Francis includes fifteen items $(\mathrm{HH})$.

First, there is (1) 'the disease of thinking we are 'immortal,' 'immune,' or downright 'indispensable'; [...] it is the disease of those who turn into lords and masters and think of themselves as above others and not at their service. It is an effect of the pathology of power, from a superiority complex." (2) "Another disease is the 'Martha complex,' excessive busy-ness [...] Jesus called his disciples to "rest a while." (3) "Then too there is the disease of mental and spiritual 'petrification'; it is found in those who have a heart of stone [...], those who lose "the sentiments of Jesus." (4) "The disease of excessive planning and of functionalism." (5) "The disease of poor coordination [that arises] once the members lose communion among themselves."

Pope Francis lists other possible diseases, such as (6) "spiritual Alzheimer's disease [which] consists of losing the memory of our personal 'salvation history,' our past history with the Lord and our 'first love' [...]. We see it in those who have lost the memory of their encounter with the Lord." (7) "The disease of rivalry and vainglory [...] [which includes] our titles of honor." (8) "The disease of existential schizophrenia; this is the disease of those who live a double life." (9) "The disease of gossiping, grumbling and back-biting [...]. Brothers, let us be on our guard against the terrorism of gossip!" (10) "The disease of idolizing superiors [...] in the hope of gaining their favor." Such Church leaders "are victims of careerism and opportunism [...]. They serve thinking only of what they can get and not of what they should give." 
The five final diseases listed by Pope Francis begin with (11) "the disease of indifference to others. This is where each individual thinks only of himself and loses sincerity and warmth in their human relationships." (12) "The disease of a lugubrious face. Those glum and dour persons who think that to be serious we have to put on a face of melancholy and severity, and treat others [...] with rigor, brusqueness and arrogance." (13) "The disease of hoarding [when one] tries to fill an existential void in his heart by accumulating material goods, not out of need but only in order to feel secure." (14) "The disease of closed circles, where belonging to a clique becomes more powerful than belonging to the Body and, in some circumstances, to Christ himself." Lastly, (15) "the disease of worldly profit, of forms of self-exhibition [which begins when] an apostle turns his service into power, and his power into a commodity in order to gain worldly profit or even greater power."

"Brothers, these diseases and these temptations are naturally a danger [...]. We need to be clear that it is only the Holy Spirit who can heal all our infirmities [...]. Let us ask the Virgin Mary [...] to make us love the Church as Christ, her Son and our Lord, loves her, to have the courage to acknowledge that we are sinners in need of his mercy [...]. And please, do not forget to pray for me! Heartfelt thanks!" (HH).

It must be noted that at Christmas in 2014, Francis gave a catalogue of fifteen "curial diseases" (which can also infect priests); then in his 2015 Christmas message he spoke about "curial antibiotics." He used an acrostic analysis of the twelve letters of the word MISERICORDIA to communicate the core of his positive message, imitating what Matteo Ricci did in his evangelizing initiatives in China. Francis concluded his reflection with the prayer attributed to Blessed Oscar Arnulfo Romero, noting that priests are to be "servants, not Messiahs" (PP).

\section{Capitalize on the "Popular Piety" of the Faithful}

In his comprehensive apostolic exhortation, The Joy of the Gospel (Evangelii Gaudium), Pope Francis devotes several sections to "the evangelizing power of popular piety" (EG 122-126). Some brief selections capture the Pope's thoughts.

"Popular piety enables us to see how the faith, once received, becomes embodied in a culture and is constantly passed on. Once looked down upon, popular piety came to be appreciated once more in the decades following the Council. In the Exhortation Evangelii Nuntiandi, Pope Paul VI gave a decisive impulse in this area. He stated that popular piety 'manifests a thirst for God which only the poor and the simple can know' and that 'it makes people 
capable of generosity and sacrifice even to the point of heroism, when it is a question of bearing witness to belief.' Closer to our own time, Benedict XVI, speaking about Latin America, pointed out that popular piety is 'a precious treasure of the Catholic Church,' in which 'we see the soul of the Latin American peoples"' (EG 123).

"The Aparecida Document [to which Francis contributed much] describes the riches which the Holy Spirit pours forth in popular piety by his gratuitous initiative. On that beloved continent, where many Christians express their faith through popular piety, the bishops also refer to it as 'popular spirituality' or 'the people's mysticism.' It is truly 'a spirituality incarnated in the culture of the lowly' [...]. It is 'a legitimate way of living the faith, a way of feeling part of the Church and a manner of being missionaries;' it brings with itself the grace of being a missionary, of coming out of oneself and setting out on pilgrimage" (EG 124).

"Underlying popular piety as a fruit of the inculturated Gospel is an active evangelizing power which we must not underestimate; to do so would be to fail to recognize the work of the Holy Spirit. Instead, we are called to promote and strengthen it, in order to deepen the never-ending process of inculturation. Expressions of popular piety have much to teach us; for those who are capable of reading them, they are a locus theologicus which demands our attention, especially at a time when we are looking to the new evangelization" (EG 126).

Before he was elected pope, the then-Cardinal Jorge Bergoglio spoke in a 2012 lecture about the "theology of the people," which he holds in high esteem. He explained the inner sense of this "theology of the people," emphasizing that popular piety is the antithesis of widespread secularization. This theology is founded on common peoples' culture and devotion, including their spirituality and a sense of justice; it manifests "the faith of our humble people."

For Cardinal Bergoglio, Latin America is largely characterized by poverty and Christianity; the latter is expressed by various and colorful forms of popular piety such as processions, vigils, and public prayer. He said: "When we approach our people with the gaze of the good shepherd, when we do not come to judge but to love, we can find out that this cultural way to express the Christian faith is still present among us, especially in our poor." He affirmed that "popular spirituality is the original way through which the Holy Spirit has led and continues to lead millions of our brothers."

Cardinal Bergoglio himself promoted various forms of popular piety in Buenos Aires. For example, he popularized the devotion to "Our Lady, Undoer of Knots." He propagated the suggestive image of La Virgen Desatanudos, a title originating in Augsburg, Germany [Maria Knotenlöserin]. He has also popularized the image of the "Sleeping Saint Joseph." Cardinal Tagle of Manila has affirmed that Pope Francis is very comfortable with popular religios- 
ity because it is a means "to strengthen the faith;" in popular piety, "the Holy Spirit and the culture of the poor meet." Undoubtedly, popular piety is a rich foundation upon which priests can build their pastoral ministry!

\section{Be Genuinely Sensitive to Those on the "Fringes" and "Margins"}

From the very beginning of his ministry as Bishop of Rome, Pope Francis has asserted that a priest's authority is always linked to his service, especially the care and protection of the poorest, weakest, the least important, the most needy, those readily forgotten, the marginalized, and those on the fringes of society. In Argentina, Francis was known as the "slum bishop" for his regular contact with the poor; he believes that such service is the most concrete way of serving Jesus. As Pope he has gone to the jail for juveniles in Rome; he has traveled to the southern Italian island of Lampedusa to be in solidarity with the numerous migrants, many of whom have died in their effort to get to Europe.

"As priests, we identify with people who are excluded, people the Lord saves. We remind ourselves that there are countless masses of people who are poor, uneducated, prisoners, who find themselves in such situations because others oppress them. But, we too remember that each of us knows the extent to which we too are often blind [...]. Jesus comes to redeem us, to send us out, to transform us from being poor and blind, imprisoned and oppressed, to become ministers of mercy and consolation" (QQ).

"As priests, we are witnesses to and ministers of the ever-increasing abundance of the Father's mercy; we have the rewarding and consoling task of incarnating mercy, as Jesus did, who 'went about doing good and healing' (Acts 10:38) in a thousand ways so that it could touch everyone. We can help to inculturate mercy, so that each person can embrace it and experience it personally" (QQ).

Francis asserts that priests need a "priestly gaze" which enables them to "see people with the eyes of mercy. It has to be learned from the seminary on, and it must enrich all our pastoral plans and projects [...]. We have to let ourselves be moved by people's situations, which at times is a mixture of their own doing, human weakness, sin and insuperable conditionings. We have to be like Jesus, who was deeply moved at the sight of people and their problems [...]. He healed people, forgave their sins, eased their suffering, gave them rest and made them feel the consoling breath of the Spirit" (VV).

Addressing bishops, priests, and religious in the Manila Cathedral in 2015, Francis emphasized the challenge to serve the poor and needy, "those living in the midst of a society burdened by poverty and corruption, tempted to give up." The clergy faces the "challenge of proclaiming the radicalism of the Gos- 
pel in a society which has grown comfortable with social exclusion, polarization, and scandalous inequality;" they must remember that "the poor are at the center of the Gospel, are at the heart of the Gospel; if we take away the poor from the Gospel we cannot understand the whole message of Jesus Christ" (II). In short, for Pope Francis "all of us are asked to obey His [Jesus'] call to go forth from our own comfort zone in order to reach all the 'peripheries' in need of the light of the Gospel" (EG 20).

\section{In Everything, Be a Genuine "Missionary Disciple"}

In Evangelii Gaudium, Pope Francis proposes a profound missionary renewal of the entire Church; certainly the clergy are central to this renewal. Francis asserts that we need an "evangelizing Church that comes out of herself," not a Church that is "self-referential" and "lives within herself, of herself, for herself." "I dream of a 'missionary option,' that is, a missionary impulse capable of transforming everything, so that the Church's customs, ways of doing things, times and schedules, language and structures can be suitably channeled for the evangelization of today's world rather than for her self-preservation [...]. All renewal in the Church must have mission as its goal if it is not to fall prey to a kind of ecclesial introversion" (EG 27).

"Missionary outreach is paradigmatic for all the Church's activity [...]. We need to move "from a pastoral ministry of mere conservation to a decidedly missionary pastoral ministry" (EG 15). "I want to emphasize that what I am trying to express here has programmatic significance and important consequences [...]. Throughout the world, let us be 'permanently in a state of mission"” (EG 25).

A pivotal insight of Pope Francis is that "we are all missionary disciples" (EG 119); through baptism, "all the members of the People of God have become missionary disciples" (EG 120). All Christians are "agents of evangelization." "The new evangelization calls for personal involvement on the part of each of the baptized [...]. Every Christian is a missionary to the extent that he or she has encountered the love of God in Christ Jesus: we no longer say that we are 'disciples' and 'missionaries,' but rather that we are always 'missionary disciples" (EG 120). "May the world of our time, which is searching, sometimes with anguish, sometimes with hope, be enabled to receive the good news not from evangelizers who are dejected, discouraged, impatient or anxious, but from ministers of the Gospel whose lives glow with fervor, who have first received the joy of Christ (EG 10; cf. EN 75).

Francis asserts: "Being a Christian is not the result of an ethical choice or a lofty idea, but the encounter with an event, a person, which gives life a new 
horizon and a decisive direction" (EG 8; cf. Benedict XV). For Pope Francis, every Christian "ought to grow in awareness that he himself is continually in need of being evangelized" (EG 164). In Chapter Two (EG 50-109), Francis focuses on the challenges facing the proclamation of the Gospel today; the pope asserts: "Challenges exist to be overcome! Let us be realists, but without losing our joy, our boldness and our hope-filled commitment. Let us not allow ourselves to be robbed of missionary vigor" (EG 109). Or again, "I repeat: Let us not allow ourselves to be robbed of the joy of evangelization" (EG 83).

\section{Conclusion}

This modest presentation has sought to highlight ten pivotal characteristics emerging from Pope Francis' profound vision of the priesthood. For the sake of clarity, the copious material of Francis has been thematically arranged under ten foundational insights that form an integrated whole. Another writer may have chosen a different style of presentation. However, what remains crucial is for readers to penetrate the insightful wisdom of Pope Francis; truly, this thematic arrangement is quite secondary to the original papal material.

Pope Francis' thoughts on the priesthood emerge from his deep convictions. Early in his pontificate, Francis wrote: "Mission is at once a passion for Jesus and a passion for his people. When we stand before Jesus crucified [...], we realize once more that he wants to make use of us to draw closer to his beloved people. He takes us from the midst of his people and he sends us to his people; without this sense of belonging, we cannot understand our deepest identity" (EG 268). Again in his message for World Mission Sunday 2015, Francis asserted: "Mission is a passion for Jesus and at the same time a passion for his people." In his address to the 2016 assembly of the Pontifical Missionary Societies, Francis spoke of "the passion for God and for the mission of the Church;" he left his audience (and us) with a clear challenge: "We must grow in evangelizing passion!" (XX).

\section{ABSTRACT}

Employing ten representative themes emerging from the speeches and writings of Pope Francis, this medium-length presentation explores the rich treasures of the Pope's insights on the topic of priesthood and priestly ministry. Twenty-four of his most relevant documents ranging from 2013 to 2016 are quoted directly; additional background material is also provided. The engaging vision of Pope Franciscus is eminently practical, grounded in pastoral realities, profoundly spiritual, and filled with 
missionary dynamism. For Pope Francis, priests must have "a passion for Jesus and a passion for His people" (Evangelii Gaudium 268).

Keywords: Pope Francis, Priesthood, Priestly Spirituality, Evangelization, Missionary Joy, Preaching, Popular Piety

Słowa kluczowe: papież Franciszek, kapłaństwo, duchowość kapłańska, ewangelizacja, radość misyjna, głoszenie, pobożność ludowa

\section{PITOVAL BIBLIOGRAPHICAL SOURCES}

INTRODUCTION. The material by Pope Francis on the Priesthood is extremely rich and plentiful. It is available to readers in a variety of internet and printed sources; often the very same document is found in various digital and printed forms. To facilitate the documentation of the quotes of Pope Francis in this presentation, a simple reference system is employed. Each of the cited documents containing specific "priesthood material" from Pope Francis is identified with double letters of the alphabet; an interested researcher could easily locate the specific document, no matter in what format or language it appears. All one needs to do is to check this bibliography to find the date and description of a specific document of the pope. In the text of this presentation, only the double letters appear at the end of a given quote. Hopefully, this simple approach avoids an overly complicated and cumbersome manner of documentation, while providing the source of the specific quote from Pope Francis. The material appearing below is presented in chronological order, beginning in 2013 and extending to 2016.

\footnotetext{
AA - March 28, 2013: Chrism Mass Homily in Saint Peter's Basilica

BB - April 21, 2013: Ordination Homily of ten priests in Saint Peter's Basilica

CC - November 24, 2013: Apostolic Exhortation Evangelii Gaudium

DD - 2013: Book by Jorge Bergoglio and Abraham Skorka: On Heaven and Earth

EE - April 17, 2014: Chrism Mass Homily in Saint Peter's Basilica

FF - May 11, 2014: Ordination Homily of thirteen priests in Saint Peter's Basilica

GG - June 6, 2014: Morning Mass Homily in Casa Santa Marta

HH - December 22, 2014: Address to the Roman Curia

II - January 16, 2015: Homily to the Clergy in the Manila Cathedral

JJ - February 14, 2015: Address at Public Consistory for the Creation of New Cardinals

KK - April 2, 2015: Chrism Mass Homily in Saint Peter's Basilica

LL - April 26, 2015: Ordination Homily of nineteen new priests in Saint Peter's Basilica

MM - May 2, 2015: Homily at North American College in Rome to celebrate "Pope's Day"

NN - August 6, 2015: Homily on the Feast of the Transfiguration of the Lord

OO - November 20, 2015: Speech to Conference on "Priesthood" Documents of Vatican II

PP - December 21, 2015: Address to the Roman Curia

QQ - March 24, 2016: Chrism Mass Homily in Saint Peter's Basilica

RR - April 17, 2016: Homily to Priests on World Day of Prayer for Vocations

SS - May 29, 2016: Homily at Jubilee for Deacons

TT - June 2, 2016: First Meditation at Jubilee for Priests

UU - June 2, 2016: Second Meditation at Jubilee for Priests

VV - June 2, 2016: Third Meditation at Jubilee for Priests
} 
WW - June 3, 2016: Homily at Mass for Feast of the Sacred Heart of Jesus

XX - June 4, 2016: Address to Assembly of the Pontifical Missionary Societies

JAMES H. Kroeger, MM, has served mission in Asia (Philippines and Bangladesh) since 1970, working in parishes and serving mostly in the education-formation apostolate of seminarians, catechists, and lay leaders. Currently he teaches Christology, Ecclesiology, Missiology, and "Asian Theology" at Loyola School of Theology, East Asian Pastoral Institute, and Mother of Life Catechetical Center in Metro Manila. He has written extensively on Asian (FABC) and Philippine theology, mission, interfaith dialogue, and on the Second Vatican Council. His recent books include: Asia's Dynamic Local Churches (Claretians - Manila); Becoming Missionary Disciples (PMS - Manila); A Vatican II Journey: Fifty Milestones and Walking in the Light of Faith (ST PAULS - Manila); and The Gift of Mission (Orbis Books - Maryknoll, New York). 


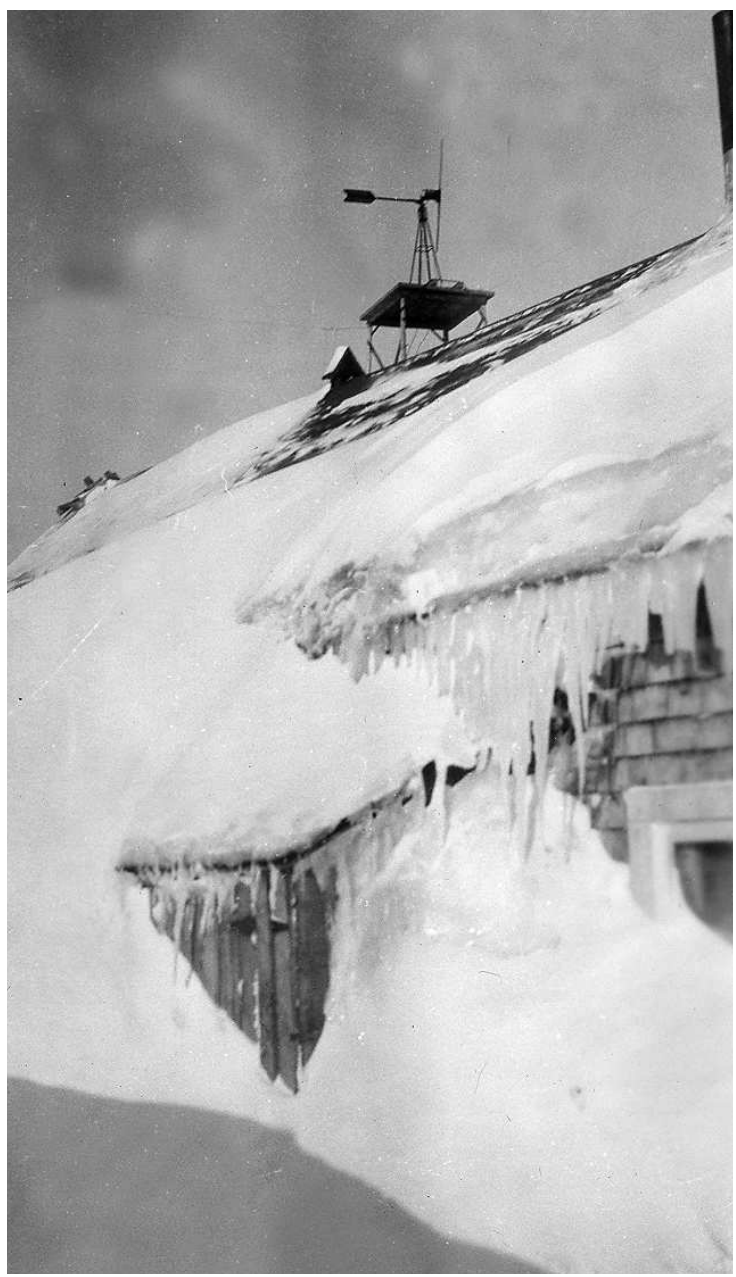

Vieux Comptoir - po burzy śnieżnej

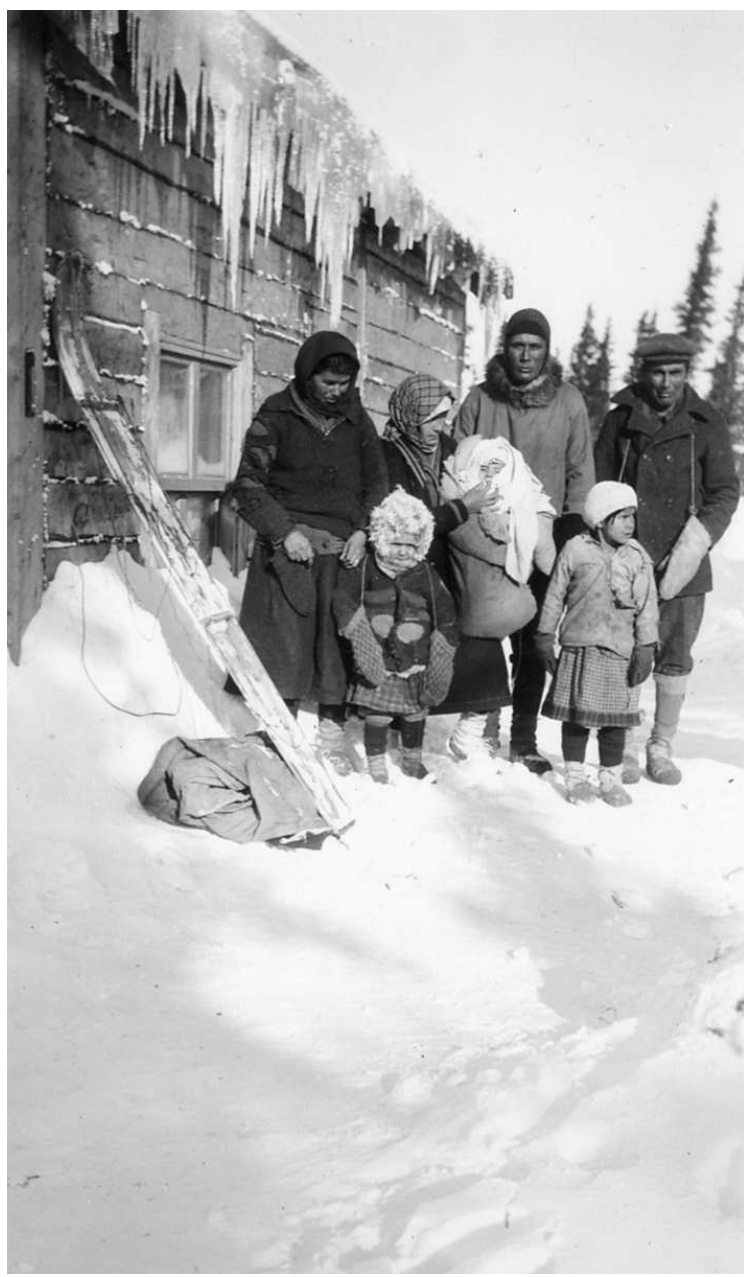

Vieux Comptoir - 8 lutego 1938 